\title{
Research progress on the dairy cow mastitis
}

\author{
Ping $X u$ \\ afraxp1986@126.com \\ Faculty of Veterinary Medicine, Sumy National Agrarian University, \\ 160 Herasima Kondratieva str., Sumy, 40021, Ukraine
}

Mastitis is an inflammatory disease of the mammary gland, which has a significant economic impact and is an animal welfare concern. Mammary gland development and regression was directly related with cow lactation. Many different microbial and environmental factors can induce mastitis. Escherichia coli and Staphylococcus aureus were the main cause of mastitis. The treatment of clinical and subclinical mastitis mainly focuses on the use of antibiotics. At present, although some progress has been made in the clinical diagnosis, antibiotic treatment, and pathogenesis control of dairy cow mastitis, the molecular mechanism of the pathogenicity of dairy cow mastitis was still not very clear. So, it is important to understand the mechanisms controlling the immune response at the molecular level. Non-coding RNAs play an important role in various biological processes, including cell proliferation, differentiation and apoptosis. However, their functions and profiles in dairy cows are largely unknown. This study reviewed the research progress of the pathogenesis, prevention measures and immune mechanism of dairy cow mastitis.

Key words: dairy cow, mastitis, etiology, immune mechanism, research status

\section{Etiology and treatment of the dairy cow mastitis}

Dairy cow mastitis is an inflammatory reaction caused by a variety of pathogens. It is also one of the most serious diseases in dairy farming. The occurrence of cow mastitis not only reduces the yield and quality of milk, but also lead to prolonged estrus time and pregnancy time after delivery of the dairy cows. Disorders can cause cows to be eliminated or even die in severe cases, causing huge economic losses to the dairy farming industry [9]. In the past few decades, the economic losses caused by dairy cow mastitis to the world dairy industry have remained basically unchanged [6]. A deeper understanding of the molecular mechanisms of mastitis in dairy cows will help to discover new ways to reduce the harm that mastitis poses to dairy farming.

Pathogenic microorganisms causing mastitis in dairy cows have been found to have at least 150 species, among which Escherichia coli, Staphylococcus aureus, Streptococcus dysgalactiae, Streptococcus uberis, and Mycoplasma [1]. Among them, Staphylococcus aureus and Escherichia coli are the most common pathogen causing mastitis in dairy cows and has been widely used to inducing pathogens in subclinical and clinical mastitis models [2]. S. aureus intramammary infection (IMI) often causes slight clinical symptoms; in contrast, E. coli IMI often leads to severe clinical mastitis, especially during calving, which seriously affects the health of the cow [4]. In the past few decades, people have been able to stably and effectively reveal specific pathogen-induced effects pathological mechanism of mastitis in dairy cows through in vivo infection experiments [13]. It has been shown that $E$. coli and $S$. aureus are effective substitutes for inducing clinical and subclinical mastitis, respectively. In addition, S. aureus secretes a variety of virulence factors during the process of infection to cause local suppurative inflammation, damage of skin and soft tissues.

In the past, antibiotic therapy was used in the treatment of mastitis in cows. However, due to the increasing resistance of pathogenic microorganisms, the effectiveness of antibiotic therapy is getting worse and worse, and antibiotic residues in dairy products are also affecting human health. Therefore, the prevention and control of the mastitis of dairy cows has always been the focus and hotspot of research.

With the development of technology, modern molecular analysis methods have provided new methods for detecting transcriptional regulation of immune-related factors in experiments over the past decade. This will help to dissect the relevant molecular mechanisms in 
the broader field of dairy mastitis and provide a basis for developing more effective ways to prevent and treat mastitis in dairy cows.

\section{Immune mechanism of the dairy cow mastitis}

When bacteria invade the mammary gland through the nipple sphincter and local catheter or through the epidermal wound, bacterial PAMPs such as LPS further activate the immune defense of the mammary gland, and neutrophils, macrophages and lymphocytes become chemotaxis into the inflammatory area to perform the immune system function [16]. In addition to exerting a barrier function, mammary epithelia I cells are also stimulated by antigen to produce an inflammatory response [5]. Interstitial fibroblasts are also involved in the process of inflammation [17]. When the mammary gland encounters bacterial invasion, macrophages in the breast tissue and milk recognize the invading pathogens and initiate an inflammatory response, while secreting various pro-inflammatory factors to recruit neutrophils to the mammary gland inflammation center area to resist the bacteria. The health mammary gland cells distributed in the breast tissue and the milk are mainly breast epithelial cells and macrophages, while the diseased tissues and the milk they secrete are mainly changed macrophages into neutrophils.

First, macrophages by releasing neutrophils and other pro-inflammatory factors to kill bacteria, such as TNF- $\alpha$, IL-1 $\beta$. while enhancing the release of prostaglandins and leukotrienes to exacerbate the inflammatory reaction. These could quickly and powerfully against the pathogen. When the pathogenic bacteria adhered the mammary epithelial cells, the mammary epithelial cells were continuously induced by toxicological components of pathogenic bacteria to produce TNF- $\alpha$, IL-6 and IL-8. Vascular endothelial cells, under the action of pro-inflammatory factors and chemokines induced by macrophages and mammary epithelial cells, secrete cell- binding molecules to attract neutrophils in the blood to the inside of the vascular endothelium. Neutrophils migrate through the gap between the epithelial cells and the subcutaneous matrix through deformation and eventually reach the infected area. Eventually most of the mastitis-causing bacteria will be recruited to the reactive oxygen species, low molecular weight antimicrobial peptides and defensins produced by neutrophils in the center of the infected area, and then the bacterial fragments will be endocytosed by phagocytes and further digested and degraded by intracellular lysosomes. When the inflammation is overreacted or out of control [18], normal cells are damaged, and the breast tissue is not restored in time.

\section{Research status of the dairy cow mastitis}

With the development of high-throughput sequencing technology, a large number of genes involved in the development of mastitis in dairy cows have been discovered $[11,14]$. The expression levels of TNF- $\alpha$, IL-8, IL-1, CXCL5, P25, P53, TGF- $\beta$ were significantly up-regulated in mastitis. At the level of microRNA research, Lawless [8] used a strain of $S$. aureus to infect mammary epithelial cells and identified a number of differentially expressed microRNAs. Subsequently, Jin [7] infected the immortalized mammary gland epithelial cell line MAC-T cells with heat-inactivated $E$. coli and $S$. aureus and obtained a differential expression map of microRNA. At the protein level, Yang [15] used an optimized protein lysate to extract breast tissue membrane proteins, and used two-dimensional gel electrophoresis separation combined with liquid chromatography tandem ion trap mass spectrometry to identify differences expressed membrane protein in breast tissue between clinically healthy and mastitis cows.

Although domestic and foreign research have conducted intensive research at various molecular levels in the past 100 years, the pathogenesis of mastitis is still not fully understood. Recent studies have found that IncRNA can participate in the regulation of inflammatory cytokines in immune inflammatory responses by interacting with protein complexes or transcription factors [12]. Elling [3] reviewed in detail the mechanism by which IncRNAs play a role in immune responses by interacting with inflammatory related genes at the DNA, RNA and protein levels. Wang et al. [10] treated the mammary gland epithelial MAC-T cells with heat-inactivated bacteria, and up-regulated tumor necrosis factor-a as an inflammatory response index and screened 53 differentially expressed IncRNAs by high-throughput sequencing. However, there is currently no report on the mechanism of IncRNA involved in regulating the occurrence of mastitis in dairy cows. Therefore, we study its mechanism of action in dairy cow mastitis from the perspective of IncRNA, which is innovative.

\section{Conclusion}

Studying the role of non-coding RNA in the pathogenesis of mastitis provides new ideas for the prevention and treatment of the dairy cow mastitis. Research in this direction will help to reduce the incidence of the dairy cow mastitis, which in its turn will increase the economic efficiency of dairy industry.

\section{Prospects for further research}

Different types of non-coding RNA (microRNA, IncRNA, circRNA) targeted regulation in the pathogenesis and treatment of dairy cow mastitis.

1. Bradley A. Bovine mastitis: an evolving disease. Vet. J. 2002; 164 (2): 116-128. DOI: 10.1053/tvjl.2002.0724. 
2. Burvenich C, Van Merris V, Mehrzad J, Diez-Fraile A, Duchateau L. Severity of $E$. coli mastitis is mainly determined by cow factors. Vet. Res. 2003; 34 (5): 521-564. DOI: 10.1051/ vetres:2003023.

3. Elling R, Chan J, Fitzgerald KA. Emerging role of long noncoding RNAs as regulators of innate immune cell development and inflammatory gene expression. Eur. J. Immunol. 2016; 46 (3): 504-512. DOI: 10.1002/eji.201444558.

4. Ganda EK, Gaeta N, Sipka A, Pomeroy B, Oikonomou G, Schukken YH, Bicalho RC. Normal milk microbiome is reestablished following experimental infection with Escherichia coli independent of intramammary antibiotic treatment with a third-generation cephalosporin in bovines. Microbiome. 2017; 5 (1): 74. DOI: 10.1186/s40168-017-0291-5.

5. He G, Ma M, Yang W, Wang H, Zhang Y, Gao MQ. SDF-1 in mammary fibroblasts of bovine with mastitis induces EMT and inflammatory response of epithelial cells. Int. J. Biol. Sci. 2017; 13 (5): 604-614. DOI: 10.7150/ijbs. 19591.

6. Hogeveen H, Huijps K, Lam TJGM. Economic aspects of mastitis: new developments. New Zeal. Vet. J. 2011; 59 (1): 16-23. DOI: 10.1080/00480169.2011.547165.

7. Jin W, Ibeagha-Awemu EM, Liang G, Beaudoin F, Zhao X, Guan LL. Transcriptome microRNA profiling of bovine mammary epithelial cells challenged with Escherichia coli or Staphylococcus aureus bacteria reveals pathogen directed microRNA expression profiles. BMC Genom. 2014; 15 (1): 181. DOI: 10.1186/1471-2164-15-181.

8. Lawless N, Foroushani ABK, McCabe MS, O'Farrelly C, Lynn DJ. Next generation sequencing reveals the expression of a unique miRNA profile in response to a gram-positive bacterial infection. Plos One. 2013; 8 (3): e57543. DOI: 10.1371/journal. pone.0057543.

9. Seegers H, Fourichon C, Beaudeau F. Production effects related to mastitis and mastitis economics in dairy cattle herds. Vet. Res. 2003; 34 (5): 475-491. DOI: 10.1051/vetres:2003027.
10. Wang $\mathrm{H}$. Identification and functional verification of IncRNA related to mastitis in dairy cows. Northwest Agriculture and Forestry Technology University. 2018. (in Chinese)

11. Wang X, Xiu L, Hu Q, Cui X, Liu B, Tao L, Wang T, Wu J, Chen Y, Chen $Y$. Deep sequencing-based transcriptional analysis of bovine mammary epithelial cells gene expression in response to in vitro infection with Staphylococcus aureus stains. Plos One. 2013; 8 (12): e82117. DOI: 10.1371/journal.pone.0082117.

12. Wei T, Yang M, Tang Q, Zhong R. Research progress of longchain non-coding RNA in immune inflammatory response. Lab. Med. 2015; 30 (10): 1044-1047. DOI: 10.3969/j.issn.16738640.2015.10.019. (in Chinese)

13. Wellnitz $O$, Bruckmaier RM. The innate immune response of the bovine mammary gland to bacterial infection. Vet. J. 2012; 192 (2):148-152. DOI: 10.1016/j.tvjl.2011.09.013.

14. Whelehan CJ, Meade KG, Eckersall PD, Young FJ, O'Farrelly C. Experimental Staphylococcus aureus infection of the mammary gland induces region-specific changes in innate immune gene expression. Vet. Immunol. Immunopathol. 2011; 140 (3-4): 181-189. DOI: 10.1016/j.vetimm.2010.11.013.

15. Yang Y, Zhang Y, Zhou L, Cheng G, Tao J, Zhao X. Comparative proteomics study of breast membrane proteins in dairy cow mastitis. National Agricultural Sciences, 2010; 43 (18): 3862-3868.

16. Yu X, Feng B, He P, Shan L. From chaos to harmony: responses and signaling upon microbial pattern recognition. Annual Rev. Phytopathol. 2017; 55: 109-137. DOI: 10.1146/annurev-phyto080516-035649.

17. Zhang W, Li X, Xu T, Ma M, Zhang Y, Gao MQ. Inflammatory responses of stromal fibroblasts to inflammatory epithelial cells are involved in the pathogenesis of bovine mastitis. Exp. Cell Res. 2016; 349 (1): 45-52. DOI: 10.1016/j.yexcr.2016.09.016.

18. Zhang WY, Wang H, Qi S, Wang X, Li X, Zhou K, Zhang Y, Gao MQ. CYP1A1 relieves lipopolysaccharide-induced inflammatory responses in bovine mammary epithelial cells. Mediators Inflamm. 2018; 5: 4093285. DOI: 10.1155/2018/4093285.

\section{Прогрес у дослідженні маститу молочних корів}

Пінг Сюй

afraxp1986@126.com

Факультет ветеринарної медицини, Сумський національний аграрний університет, вул. Герасима Кондратьєва, 160, м. Суми, 40021, Україна

Мастит - це запальне захворювання молочної залози, яке призводить до значних економічних збитків і спричиняє проблеми життєздатності тварин. Розвиток і регресія молочних залоз безпосередньо пов'язані з лактацією корів. Багато різних мікробних та екологічних чинників можуть провокувати мастит. Escherichia coli i Staphylococcus aureus були основною причиною маститу. Лікування клінічного та субклінічного маститу переважно зосереджене на застосуванні антибіотиків. Хоча на сьогодні досягнуто певного прогресу в клінічній діагностиці маститів, лікування антибіотиками, патогенетичний контроль та молекулярний механізм патогенності маститів молочних корів все ще недостатньо вивчені. Отже, важливо зрозуміти механізми контролю імунної відповіді на молекулярному рівні. Некодуючі РНК відіграють важливу роль у різних біологічних процесах, зокрема проліферації клітин, диференціюванні та апоптозу. Однак їхні функції та профрілі у молочних корів значною мірою невідомі. Тут представлено огляд прогресу досліджень патогенезу, заходів профілактики та імунного механізму маститу молочних корів.

Ключові слова: молочна корова, мастит, етіологія, імунний механізм, статус дослідження 